\title{
46. ORGANIC AND INORGANIC NITROGEN IN SEDIMENTS FROM LEG 80, DEEP SEA DRILLING PROJECT ${ }^{1}$
}

\author{
Douglas W. Waples, Mobil Research and Development Corporation, Dallas ${ }^{2}$
}

\begin{abstract}
Concentrations of organic and inorganic nitrogen have been measured on Leg 80 sediments. The inorganic nitrogen content is relatively constant, $0.02-0.03 \mathrm{wt}$. \% . Because most of the inorganic nitrogen occurs as $\mathrm{NH}_{3}$ or $\left(\mathrm{NH}_{4}\right)^{+}$fixed on clays, clay-poor sediments have lower inorganic nitrogen contents.

Organic nitrogen content depends upon both the type and the quantity of organic matter present. In Leg 80 sediments, woody kerogens contain much less organic nitrogen than do kerogens of algal origin. Furthermore, pelagic samples of low organic carbon content have less organic nitrogen than predicted, because of loss during diagenesis.

DSDP shipboard analytical procedures do not distinguish between organic and inorganic nitrogen. Great caution must therefore be exercised in interpreting $\mathrm{C} / \mathrm{N}$ ratios.
\end{abstract}

\section{INTRODUCTION}

Acid-insoluble nitrogen and organic carbon contents of DSDP sediments have frequently been measured on board ship since at least Leg 41 . The authors on Leg 43 (Tucholke, Vogt, et al., 1979) recognized that interpretation of nitrogen contents and $\mathrm{C} / \mathrm{N}$ ratios might be complicated by the presence of inorganic nitrogen, a suggestion which had been made earlier by Forsman and Hunt (1958) and Stevenson and Cheng (1972). The analytical procedure for nitrogen determination used on the Glomar Challenger involves combustion of carbonate-free rock samples, rather than of kerogen or kerogen concentrates. Combustion of isolated kerogen, the approach generally used in shore-based work, is a superior method for measuring organic nitrogen, but is impossible on the Glomar Challenger because of regulations prohibiting the use of hydrofluoric acid.

It has been tempting to utilize $\mathrm{C} / \mathrm{N}$ data generated on the Glomar Challenger as though the nitrogen measured were entirely organic (e.g., Waples and Sloan, 1980). As Arrhenius (1950), Stevenson and Cheng (1972), and Tucholke, Vogt, et al. (1979) have noted, however, C/N ratios in sediments with low contents of organic matter may be strongly influenced by the inorganic nitrogen present as ammonia or as ammonium ion fixed on clays.

Investigations at Leg 80 sites show that inorganic nitrogen may indeed in certain cases be the dominant component of the total nitrogen present in the sediments, and may therefore invalidate interpretations based on the assumption that all nitrogen is organic. $\mathrm{C} / \mathrm{N}$ ratios measured on whole or carbonate-free rock samples should therefore be used with caution.

\section{ANALYTICAL METHODS}

Sediment and rock samples $\left(3 \mathrm{~cm}^{3}\right)$ were immediately placed in a drying oven at $80^{\circ} \mathrm{C}$ for several hours. They were then crushed with a porcelain mortar and pestle, and redried briefly at $80^{\circ} \mathrm{C}$. A 0.5 to

\footnotetext{
${ }^{1}$ Graciansky, P. C. de, Poag, C. W., et al., Init. Repts. DSDP, 80: Washington (U.S. Govt, Printing Office).

2 Present address: 1717 Place One Lane, Garland, TX 75042.
}

$1.0 \mathrm{~g}$ aliquot was treated with excess concentrated hydrochloric acid in the shipboard "Carbonate Bomb," as described by Müller and Gastner (1971), to measure $\mathrm{CaCO}_{3}$ content and remove inorganic carbon. The carbonate-free residues were rinsed three times with deionized water while being suction-filtered through sintered-glass filters. The rinsed residues were redried at $80^{\circ} \mathrm{C}$, crushed, and analyzed for carbon and nitrogen.

The C-H-N analyzer (Hewlett-Packard Model 185B) was standardized with appropriate shipboard standards. Samples (5 to $40 \mathrm{mg}$, depending upon carbon content) were burned at $1050^{\circ} \mathrm{C}$, and the evolved $\mathrm{CO}_{2}$ and $\mathrm{N}_{2}$ gases were measured. Gas peaks were integrated automatically, and appropriate blanks were run. No effort was made to obtain organic hydrogen data from the $\mathrm{H}_{2} \mathrm{O}$ peak, because of the presence of adsorbed water in clay and other minerals. Carbon and nitrogen contents of the carbonate-free material were corrected for the carbonate removed by acid treatment by multiplying by (100 $\left.\% \mathrm{CaCO}_{3}\right) / 100$.

Shipboard carbonate-bomb analyses are accurate to within 3\% absolute (Tucholke and Vogt, 1979). Organic carbon and organic nitrogen analyses on the H-P 185B are reproducible to within $0.03 \%$ (carbon) and $0.005 \%$ (nitrogen).

Determinations of inorganic nitrogen contents were carried out at Mobil Field Research Laboratory according to procedure A of Silva and Bremner (1966). Exchangeable ammonia and organic nitrogen were removed with alkaline $\mathrm{KOBr}$. Nonexchangeable (fixed) ammonia was then released by treatment with an $\mathrm{HCl} / \mathrm{HF}$ mixture, and the ammonia content was determined by steam distillation and titration.

\section{RESULTS AND DISCUSSION}

Carbonate, organic carbon, and total nitrogen contents of all samples from Sites 548, 549, 550, and 551 are reported elsewhere (Waples and Cunningham, this volume). In addition, inorganic nitrogen contents were determined for selected samples from Sites 549 and 550 (Table 1).

An investigation of the relationship betwen total organic carbon (TOC) and total nitrogen contents was carried out for samples from Sites 549 and 550. Samples from Sites 548 and 551 were not used in this study, because those samples had uniformly low organic carbon contents.

A plot of TOC versus total nitrogen for carbonatefree residues of Site 549 samples from sublittoral to upper bathyal depositional environments (Hole 549, Cores 32-93) shows a linear relationship (Fig. 1). The best least- 
Table 1. Analyses (in \%) of samples from Holes 549 and 550B, giving organic and inorganic nitrogen contents.

\begin{tabular}{|c|c|c|c|c|c|}
\hline $\begin{array}{c}\text { Sample } \\
\text { (interval in } \mathrm{cm} \text { ) }\end{array}$ & TOC & $\mathrm{CaCO}_{3}$ & $\mathrm{~N}_{\text {total }}$ & $\mathrm{N}_{\text {inor }}$ & $\mathrm{N}_{\text {org }}{ }^{\mathrm{a}}$ \\
\hline \multicolumn{6}{|l|}{ Hole 549} \\
\hline $27-1,50-1$ & 3.51 & 9 & 0.161 & 0.0121 & 0.1499 \\
\hline $34-1,52-3$ & 0.25 & 51 & 0.017 & 0.0084 & 0.0086 \\
\hline $36-1,20-1$ & 0.46 & 49 & 0.023 & 0.0111 & 0.0119 \\
\hline $39-1,6-7$ & 0.43 & 32 & 0.032 & 0.0174 & 0.0146 \\
\hline $59-3,52-3$ & 0.47 & 21 & 0.036 & 0.0217 & 0.0143 \\
\hline $72-1,94-5$ & 0.67 & 16 & 0.043 & 0.0211 & 0.0219 \\
\hline $79-1,7-8$ & 4.20 & 0 & 0.101 & 0.0303 & 0.0707 \\
\hline $80-2,26-7$ & 0.11 & 31 & 0.012 & 0.0091 & 0.0029 \\
\hline $83-2,57-8$ & 0.13 & 0 & 0.026 & 0.0245 & 0.0015 \\
\hline $84-1,130-1$ & 1.52 & 2 & 0.040 & 0.0214 & 0.0186 \\
\hline $85-2,38-9$ & 3.01 & 4 & 0.065 & 0.0148 & 0.0502 \\
\hline $87-1,137-8$ & 2.75 & 2 & 0.059 & 0.0297 & 0.0293 \\
\hline $89, \mathrm{CC}$ & 0.13 & 29 & 0.020 & 0.0147 & 0.0053 \\
\hline \multicolumn{6}{|l|}{ Hole 550B } \\
\hline $2-3,29-30$ & 0.04 & 30 & 0.026 & 0.0217 & 0.0043 \\
\hline $9-4,0-1$ & 0.11 & 42 & 0.030 & 0.0214 & 0.0086 \\
\hline $13-4,121-2$ & 0.08 & 6 & 0.030 & 0.0258 & 0.0042 \\
\hline $13-5,135-6$ & 0.21 & 0 & 0.037 & 0.0259 & 0.0111 \\
\hline $13-5,140-1$ & 0.54 & 2 & 0.048 & 0.0235 & 0.0245 \\
\hline $15-3,68-9$ & 0.14 & 3 & 0.030 & 0.0211 & 0.0089 \\
\hline $15-3,116-7$ & 0.49 & 2 & 0.043 & 0.0234 & 0.0196 \\
\hline $16-1,107-8$ & 1.47 & 72 & 0.091 & 0.0054 & 0.0856 \\
\hline $17-1,56-7$ & 2.37 & 66 & 0.132 & 0.0052 & 0.1268 \\
\hline $17, \mathrm{CC}$ & 2.06 & 65 & 0.124 & 0.0108 & 0.1132 \\
\hline $20-2,42-4$ & 0.74 & 43 & 0.038 & 0.0133 & 0.0247 \\
\hline $24-3,46-7$ & 1.37 & 51 & 0.090 & 0.0198 & 0.0702 \\
\hline $24-3,55-6$ & 0.32 & 43 & 0.023 & 0.0119 & 0.0111 \\
\hline
\end{tabular}

a Calculated by $\mathrm{N}_{\text {total }}-\mathrm{N}_{\text {inor }}$.

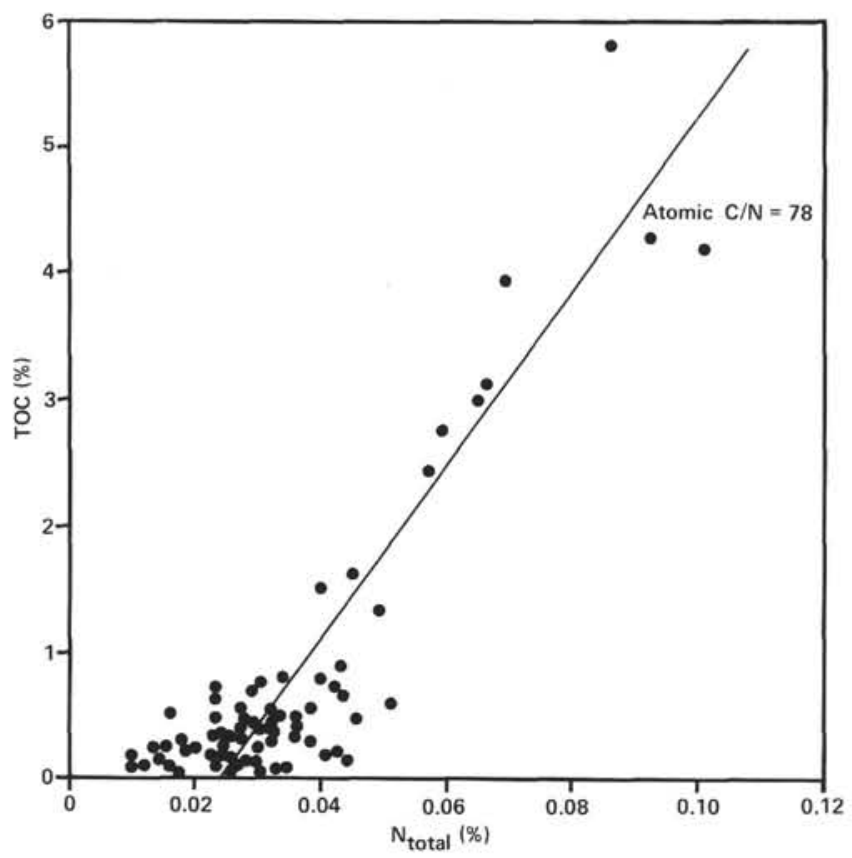

Figure 1. TOC content vs. total nitrogen content for sediments from upper bathyal to sublittoral depositional environments (Hole 549, Cores 32-93). squares line has a slope of 78 (atomic $\mathrm{C} / \mathrm{N}$ ratio), and intercept (TOC $=0 \%$ ) at $0.023 \%$ total nitrogen. The increase in total nitrogen with increasing TOC is attributed to organic nitrogen occurring together with the organic carbon. The nitrogen present at very low TOC values is inorganic, present as ammonia or ammonium ion.

Figure 2 shows the same plot for Site 550 (Hole 550B); once again the trend is linear (with a slight systematic deviation at lower carbon values), but the slope (atomic $\mathrm{C} / \mathrm{N}=18$, calculated for samples having TOC $>1 \%$ ) is much different from that for Site 549. Total nitrogen values at very low TOC values are about $0.028 \%$. The increase in total nitrogen with increasing TOC at Site 550 is also attributed to organic nitrogen.

The much higher organic nitrogen contents of the Site 550 samples (lower atomic $\mathrm{C} / \mathrm{N}$ ratios), compared with those of the Site 549 samples, indicate that the types of organic matter at the two sites are greatly different. The pelagic sediments at Site 550 contain finely divided organic matter of marine and terrestrial origin (Waples and Cunningham, this volume; Cunningham and Gilbert, this volume). As such, they should contain some organic matter of algal origin that is relatively rich in nitrogen. The sublittoral to upper bathyal Site 549 sediments, in contrast, contain almost exclusively woody, terrestrial plant fragments known to have very low nitrogen contents (Waples, 1977). The large inherent differences in nitrogen contents of these two sample suites are therefore attributed to differences in kerogen type.

This conclusion is supported by comparison of the slope of the line in Figure 1 (atomic $\mathrm{C} / \mathrm{N}=78$ ) with the nitrogen content of a pure sample of fossil wood (Sample $549-57-1,111 \mathrm{~cm}$ : atomic $\mathrm{C} / \mathrm{N}=90$ ). It is also compatible with the fact that the black shale samples from Core 549-27, which are known to contain some kerogen of algal origin (Waples and Cunningham, this volume;

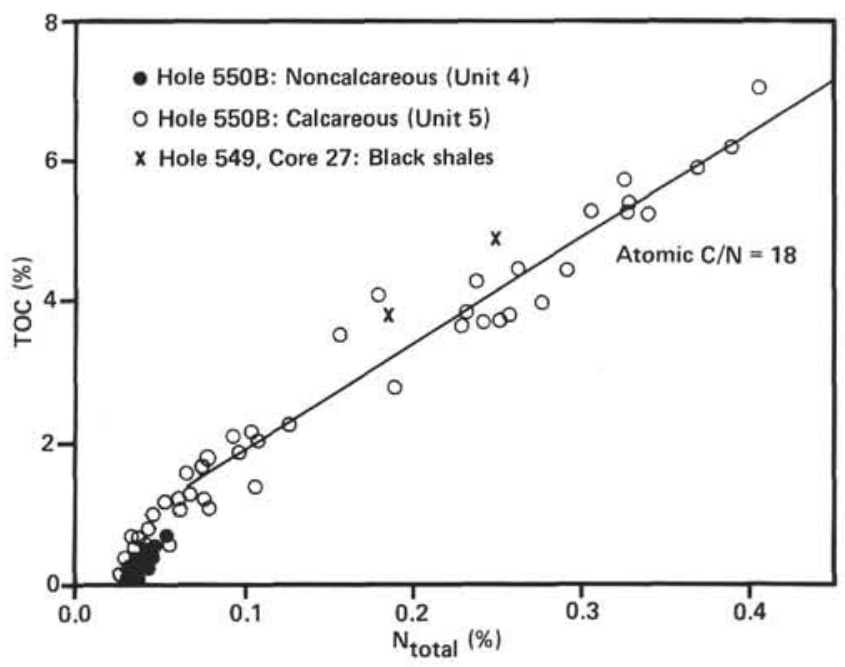

Figure 2. TOC content vs, total nitrogen content for Hole 550B pelagic sediments, Units 4 and 5. Slope of best least-squares fit, calculated for all TOC $>1.0 \%$, is 18 (atomic $\mathrm{C} / \mathrm{N}$ ratio). All TOC and nitrogen values were measured on carbonate-free residues. 
Cunningham and Gilbert, this volume), have nitrogen contents similar to those of the pelagic samples from Site 550, rather than to the sublittoral to upper bathyal Site 549 samples (Fig. 2).

The difference between organic nitrogen contents of sublittoral-upper bathyal samples and those from pelagic depositional environments is emphasized in Figure 3, where TOC is plotted against organic nitrogren. For samples having TOC values greater than $1 \%, \mathrm{TOC} / \mathrm{N}_{\text {org }}$ ratios differ by a factor of 4 to 5 , but for samples having low organic carbon contents there is no significant difference. Atomic $\mathrm{C} / \mathrm{N}$ ratios for samples of low TOC contents from both environments fall intermediate between those for the higher TOC values from the two environments ( 31 vs. 18 and 78 ). This result is interpreted to mean that in sublittoral to upper bathyal environments having low TOC values the contribution of macroscopic wood fragments was low; other fine terrestrial debris and aquatic organisms having higher nitrogen contents were the main sources of organic matter.

Pelagic sediments having low TOC values, in contrast, had lower organic nitrogen contents than predicted from the regression line for high-TOC samples. Extensive sediment diagenesis associated with the low TOC values (indicated by other geochemical data: Waples and Cunningham, this volume) was probably responsible for the lower nitrogen contents. Because nitrogen is an important nutrient, diagenesis leads to more rapid consump-

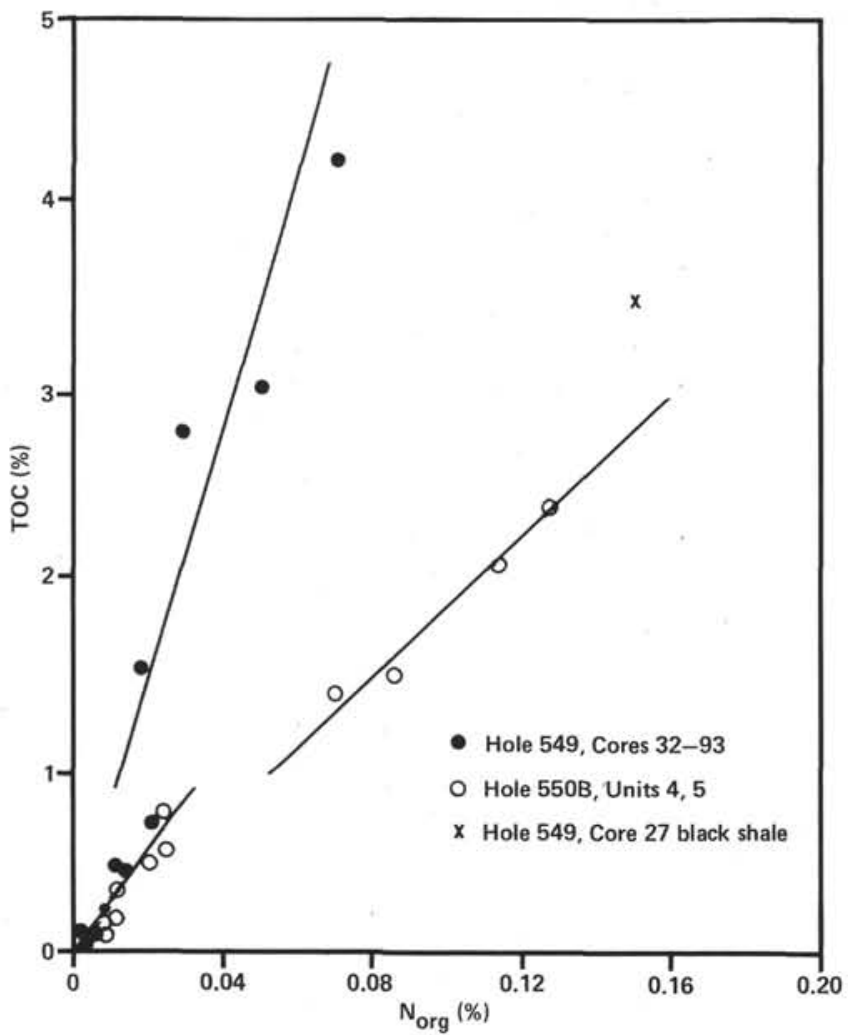

Figure 3. TOC content vs. organic nitrogen content for selected samples, Holes 549 and 550B. tion of nitrogen than of carbon, and yields residual kerogens having higher $\mathrm{C} / \mathrm{N}$ ratios (Kamatani, 1969; Sholkovitz, 1973).

Direct measurement of inorganic nitrogen contents of 26 selected samples from Sites 549 and 550 (Table 1) supports the hypothesis, derived from Figures 1 and 2, that much of the nitrogen present in sediments containing little organic matter is inorganic. Inorganic nitrogen content of these samples is independent of TOC content (Fig. 4). The average measured inorganic nitrogen content of the 26 samples on a carbonate-free basis is $0.024 \%$, virtually identical with the values of $0.023 \%$ and $0.028 \%$ obtained graphically from Figures 1 and 2 .

Inorganic nitrogen contents are directly dependent upon the clay contents of these sediments. A plot of TOC versus total nitrogen for whole sediment (corrected for carbonate removed during acidification) from Site 550 shows this relationship clearly (Fig. 5). Sediments of the noncalcareous Unit 4 plot along a trend different from that for sediments of the calcareous Unit 5, although when the samples were compared on a carbonate-free basis they plotted on the same trend (Fig. 2). Total nitrogen contents of sediments with low contents of organic carbon (TOC $<0.2 \%$ ) from all Leg 80 sites are also in-

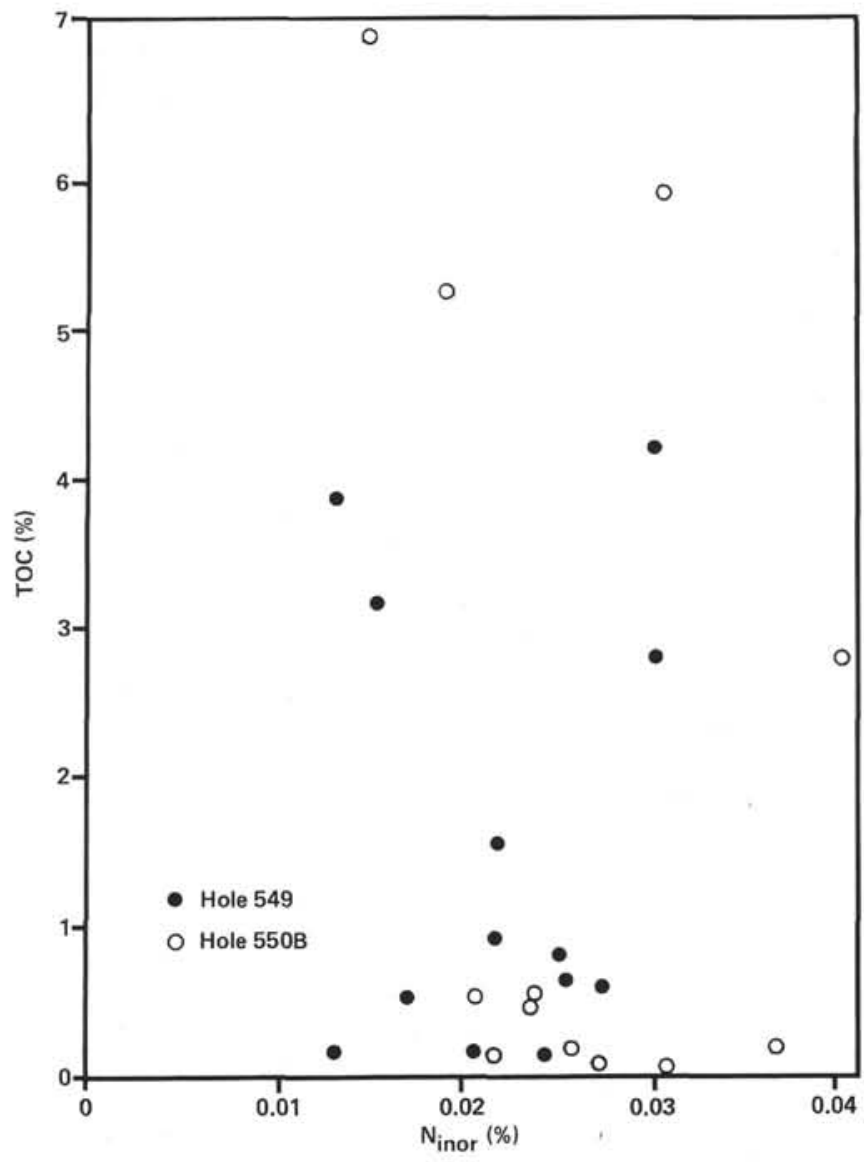

Figure 4. TOC content vs. inorganic nitrogen content for selected samples, Holes 549 and 550B. All values calculated on a carbonatefree basis from data in Table 1. 


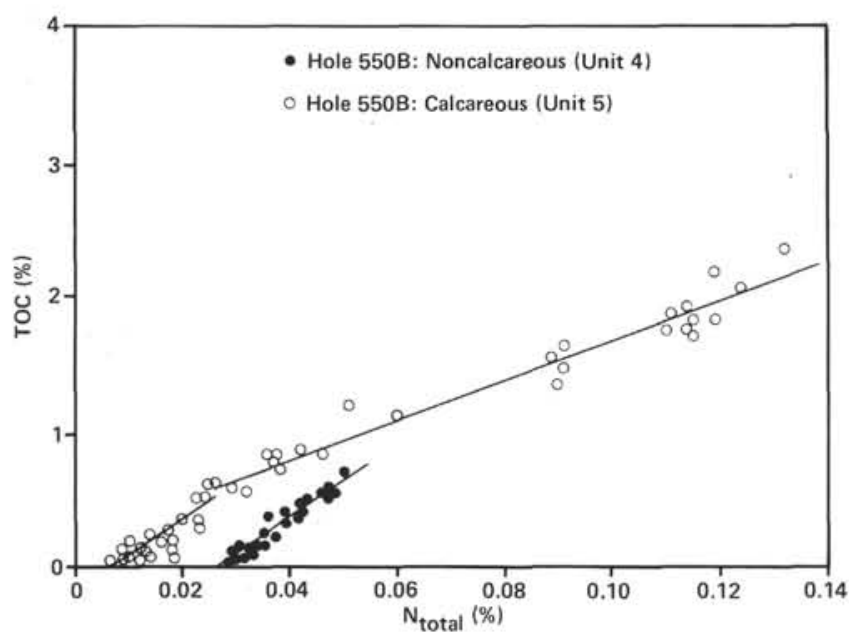

Figure 5. TOC content vs. total nitrogen content Hole 550B pelagic samples, Units 4 and 5.

versely proportional to carbonate content (Fig. 6). In these sediments it is likely that virtually all the nitrogen is inorganic.

The regular decrease in fixed nitrogen with decreasing clay content suggests that the amount of inorganic nitrogen is limited by the ability of clay minerals to fix ammonia or ammonium ion, rather than by availability of $\mathrm{NH}_{3}$ and $\left(\mathrm{NH}_{4}\right)^{+}$as degradation products of organic nitrogen. That the scatter of total nitrogen values among low-TOC samples is much greater for Site 549 than for Site 550 (Fig. 1 vs. Fig. 2) is probably related to differing clay contents or types in the noncalcareous fraction. If this interpretation is correct, the nitrogen-fixing capacity of the clays in these marine sediments $(0.024 \%=240$

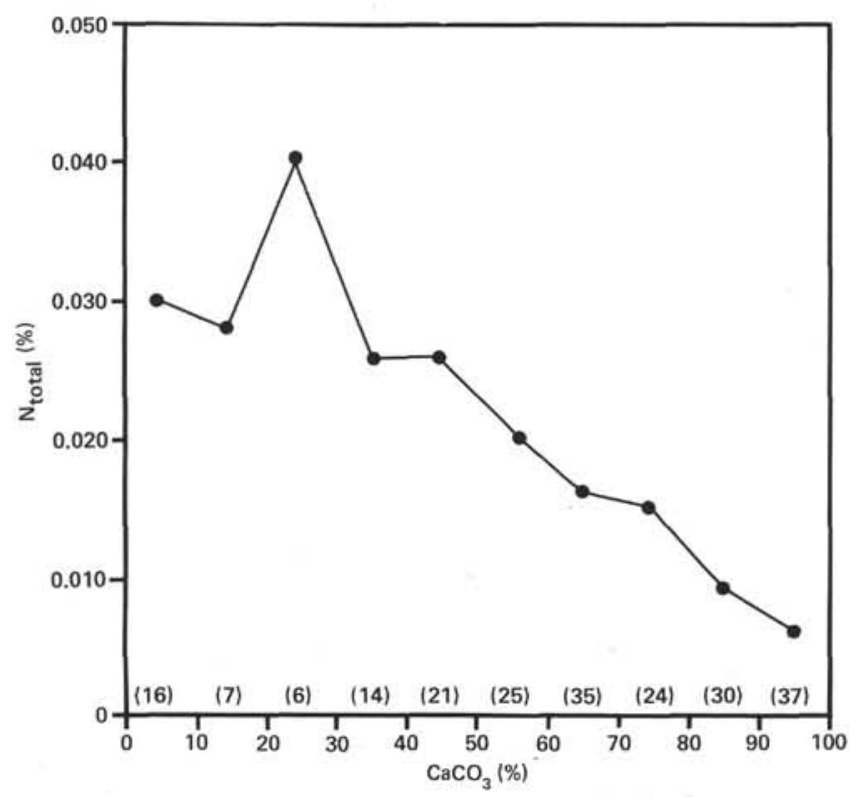

Figure 6. Total nitrogen content for Leg 80 sediments with low organic carbon contents (TOC $<0.2 \%$ ). Each point represents the median value for a $10 \%$ interval of $\mathrm{CaCO}_{3}$ content. Number of samples for each interval given in parentheses at bottom of graph. ppm) is similar to that reported by Silva and Bremner (1966) for clays in soils (average $177 \mathrm{ppm}$ ). James and Harward (1963) reported much higher values for adsorbed ammonia in pure clays, but because their analytical procedure measured exchangeable ammonium species as well as fixed ammonia, the results are not comparable.

The general conclusions of this study are entirely compatible with those of Stevenson and Cheng (1972), who found significant amounts of ammonium nitrogen fixed in clay lattices. Forsman and Hunt (1958) presented evidence that substantial amounts of free or exchangeable $\mathrm{NH}_{3}$ or $\left(\mathrm{NH}_{4}\right)^{+}$ion occur in clay-rich sediments. These exchangeable ammonia species were thus probably also present in Leg 80 samples, but were lost during the analytical procedures employed here and by Stevenson and Cheng. Such exchangeable species therefore cannot be responsible for the inorganic nitrogen values reported here for these samples.

\section{SUMMARY}

Both organic and inorganic nitrogen are present in Leg 80 sediments. Inorganic nitrogen appears to be present as ammonia or ammonium ion fixed on clay minerals. Because the quantity of inorganic nitrogen is rather constant, its concentration is probably governed primarily by the fixing capacity of the clays present, rather than by nitrogen availability. Inorganic nitrogen is the dominant form of nitrogen in samples having less than $0.5 \%$ TOC.

Organic nitrogen predominates in sediments richer in organic carbon. The amount of organic nitrogen depends not only upon TOC, but also upon the type of organic matter. Woody kerogens encountered in Leg 80 samples contain one fourth as much nitrogen as do the mixed Type II-III kerogens from pelagic settings.

Because $\mathrm{C} / \mathrm{N}$ ratios determined on rock samples include both organic and inorganic nitrogen, they cannot be compared directly with $\mathrm{C} / \mathrm{N}$ ratios determined on kerogen concentrates. $\mathrm{C} / \mathrm{N}$ ratios measured by the former method should therefore be used with extreme caution in discussing diagenesis of organic matter in sediments.

\section{ACKNOWLEDGMENT}

I thank Sam Faris and Bob Worthen for technical assistance, George Claypool and Jim Cooper for reading and criticizing the manuscript, and Mobil Research and Development Corporation for permission to publish these results.

\section{REFERENCES}

Arrhenius, G., 1950. Carbon and nitrogen in subaquatic sediments. Geochim. Cosmochim. Acta, 1:15-21.

Forsman, J. P., and Hunt, J. M., 1958. Insoluble organic matter (Kerogen) in sedimentary rocks of marine origin. In Weeks, L. G. (Ed.), Habitat of Oil: Tulsa (AAPG), pp. 747-778.

James, D. W., and Harward, M. E., 1963. Mechanism of $\mathrm{NH}_{3}$ adsorption by montmorillonite and kaolinite. In Bradley, W. F. (Ed.), Clays and Clay Minerals (Vol. 11): New York (MacMillan), 301-320.

Kamatani, A., 1969. Regeneration of inorganic nutrients from diatom decomposition. J. Ocean. Soc. Japan, 25:63-74.

Müller, G., and Gastner, M., 1971. The "Karbonat-Bombe," a simple device for the determination of the carbonate content in sediments, soils, and other materials. N. Jahrb. Mineral. Mh., 10:466-469.

Müller, P. J., 1977. C/N ratios in Pacific deep-sea sediments: effect of inorganic ammonium and organic nitrogen compounds/sorbed by clays. Geochim. Cosmochim. Acta, 41:765-776. 
Sholkovitz, E. R., 1973. Interstitial water chemistry of the Santa Barbara Basin sediments. Geochim. Cosmochim. Acta, 37:2043-2073.

Silva, J. A., and Bremner, J. M., 1966. Determination of isotope-ratio analysis of different forms of nitrogen in soils: 5 . Fixed ammonium. Soil Sci. Soc. Amer. Proc., 30:587-594.

Stevenson, F. J., and Cheng, C. N., 1972. Organic geochemistry of the Argentine Basin sediments: carbon-nitrogen relationships and Quaternary correlations. Geochim. Cosmochim. Acta, 36:653-571.

Tucholke, B. E., and Vogt, P. R., 1979. Introduction and explanatory notes, Leg 43 Deep Sea Drilling Project. In Tucholke, B. E., Vogt, P. R., et al., Init. Repts. DSDP, 43: Washington (U.S. Govt. Printing Office), 5-27.

Tucholke, B. E., Vogt, P. R., et al., 1979. Site 382: Nashville Seamount-volcanism along the eastern New England Seamount chain.
In Tucholke, B. E., Vogt, P. R., et al., Init. Repts. DSDP, 43: Washington (U.S. Govt. Printing Office), 31-93.

Waples, D. W., 1977. C/N ratios in source rock studies. Bull. Miner. Ind., Colo. School of Mines, 20(5).

Waples, D. W., and Sloan, J. R., 1980. Carbon and nitrogen profiles in deep-sea sediments: new evidence for bacterial diagenesis at great depths of burial. In Klein, G. de V., Kobayashi, K., et al., Init. Repts. DSDP, 58: Washington (U.S. Govt. Printing Office), 745-754.

Date of Initial Receipt: December 6, 1982

Date of Acceptance: July 1, 1983 